NBER WORKING PAPER SERIES

POLICY LESSONS FROM THE U.S. UNEMPLOYMENT INSURANCE EXPERIMENTS

Bruce D. Meyer

Working Paper No. 4197

\author{
NATIONAL BUREAU OF ECONOMIC RESEARCH \\ 1050 Massachusetts Avenue \\ Cambridge, MA 02138 \\ October 1992
}

Department of Economics and Center for Urban Affairs and Policy Research, Northwestern University, Evanston, IL 60208. This paper was prepared for Employment and Immigration Canada. I would like to thank Rebecca Blank, James Hanna, Robert LaLonde, John Pencavel, Ging Wong, Paula Worthington, and participants at the Canadian Employment Research Forum, The EIC Seminar on the Use of Reemployment Cash Bonus Incentives in the United States, and the University of Chicago for their comments. This paper is part of NBER's research programs in Labor Studies and Public Economics. Any opinions expressed are those of the author(s) and not those of the National Bureau of Economic Research. 
NBER Working Paper \#4197

October 1992

\title{
POLICY LESSONS FROM THE U.S. UNEMPLOYMENT INSURANCE EXPERIMENTS
}

\begin{abstract}
Recently, there has been extensive experimental evaluation of reforms of the unemployment insurance (UI) system. The UI experiments can be divided into two main areas: reemployment bonuses and job search programs. The four reemployment bonus experiments offered payments to UI recipients who found jobs quickly and kept them for a specified period of time. The six job search experiments evaluated combinations of services including additional information on job openings, more job placements, and more extensive checks of UI eligibility.

The bonus experiments show that economic incentives do affect the speed with which people leave the unemployment insurance rolls. They also show that speeding claimants' return to work appears to increase total earnings following the claim, but the evidence is less strong. They also suggest that the rate of pay on the new job is not adversely affected by an earlier return to work. Despite these encouraging results, I argue that the experiments do not show that permanent adoption of a reemployment bonus would be beneficial as they cannot account for the effect of a reemployment bonus on the size of the claimant population.

The job search experiments test several reforms that appear more promising. Nearly all of the combinations of services and increased enforcement reduce UI receipt, and have benefits that exceed costs. The treatments which mainly increase enforcement of work search rules have small but often statistically significant effects. The experiments which focus more on providing services induce much larger reductions in UI receipt, but at a higher cost of services per claimant. Nevertheless, these experiments have very favorable ratios of benefits to costs.
\end{abstract}

\author{
Bruce D. Meyer \\ Department of Economics and Center \\ for Urban Affairs and Policy Research \\ Northwestem University \\ Evanston, IL 60208 \\ and NBER
}




\section{Introduction}

Recently, there has been extensive experimental evaluation of proposed reforms of the unemployment insurance (UI) system in the U.S. The proposed reforms have generally sought to improve the reemployment prospects of UI claimants and reduce the budgetary costs of UI. These recent evaluations are novel because most have been social experiments. Individuals were randomly assigned into either a group subject to special treatment and incentives, or a group that received existing services and incentives. Despite the large number of experiments, there is no comprehensive analysis of their results to date. In this paper, I summarize what can be learned about the effects of UI policy from these experiments.

The UI experiments have taken two main forms: cash bonuses and job search programs.' Cash bonus experiments make payments to UI recipients who find jobs quickly and keep them for a specified period of time. To date, four experiments have

\footnotetext{
${ }^{1} \mathrm{~A}$ third area of experimentation has tried to encourage self-employment as an alternative to unemployment. Demonstrations are currently underway in Minnesota and Washington State. These experiments waive the work test which requires UI recipients to look for work actively. Lump sum payments to start a business are also part of both experiments, but they receive greater emphasis in Washington State. These demonstrations are not evaluated here because their goals differ from the other demonstrations and they have not been completed. It is also clear from the interim reports that self-employment only interests a few percent of UI recipients (see Johnson and Leonard (1992) and Benus et al. (1992)).
} 
examined cash bonuses. ${ }^{2}$ Job search experiments have evaluated combinations of services including additional information on job openings, more job placements, and more extensive checks of UI eligibility. To date, six experiments have analyzed various forms of job search assistance. ${ }^{3}$

\section{THE REASONS FOR THE EXPERIMENTS}

Several forces seem to have caused this outburst of experimentation. Recently, there has been increased concern about both the long-term unemployed and displaced workers. Between 1975 and 1985 the unemployment rate was persistently higher than it had been in the first 30 years after World War II. Much of this change was attributed to increases in unemployment among people with very long periods of joblessness.

Structural changes in the economy seemed to be eliminating a large number of jobs. The Bureau of Labor Statistics estimates that 5.1 million workers with at least three years of job tenure became separated from their employer during the $1981-85$ period. These increases in joblessness seemed to call for new measures to provide for the unemployed.

'The four bonus experiments are the Illinois UI Incentive Experiments, New Jersey UI Reemployment Demonstration, Pennsylvania Reemployment Bonus Demonstration, and Washington Reemployment Bonus Experiments.

${ }^{3}$ The six job search experiments are the Nevada Claimant Placement Program, Charleston Claimant Placement and Work Test Demonstration, New Jersey UI Reemployment Demonstration, Nevada Claimant Employment Program, Washington Alternative Work Search Experiment, and Re-Employ Minnesota. 
Identifying displaced workers and targeting services to them was one goal of the experiments.

On the other hand, the large increases in unemployment during this period drained state UI trust funds forcing many states to borrow to pay their benefits. By the beginning of 1983,28 states owed $\$ 13.7$ billion to the federal government. The sorry financial state of the UI system pushed many policy makers to look for ways to save money on UI programs. Reducing the costs of the UI program was a goal of all of the experiments. There has recently also been a growing desire to get the unemployed back to work. The experiments emphasize this objective. These forces seem to have been a particularly important impetus in the case of the bonus experiments.

The job search experiments were spurred by these forces as well as ideas about reforming UI operations. Some of the early experiments pointed to abuses of the UI system such as overpayments. A prime cause of overpayments that is mentioned is the failure of claimants actively to seek work. These experiments also mentioned a conflict between the goals of the UI offices which must monitor eligibility and the state Employment Service (ES) which refers people to jobs. Often these two functions are provided in different locations and they are generally provided by different individuals. While the conflict is often described in vague terms, it seems that the ES has an incentive to be more selective in whom it refers to employers than might be desirable for the UI

\footnotetext{
‘See Anderson, Corson and Decker (1990), p. 1.
} 
system in the short-run. Several of the experiments sought to increase UI/ES cooperation. $^{s}$

The first bonus experiment, which took place in Illinois, was a state effort. The Illinois experiment appeared to be very successful. This success spurred further experimentation, much of it hoping to fine tune the bonus idea rather than firmly establish whether the broad idea of bonuses makes sense. ${ }^{6}$ The three bonus experiments that followed were partly supported by the U.S. Department of Labor. Most of the other experiments were at least partly supported by the Department of Labor, but some were wholly state funded.

\section{THE USE OF RANDOM ASSIGNMENT}

These UI demonstrations are novel because they are all examined through random assignment. Whether a claimant is assigned to a treatment group or the control group is usually determined by the last two digits of his or her social security number. Estimates of the effect of the programs can be made by comparing outcome measures such as benefits paid or earnings for those who received the special treatment to the same measures for those who did not. At least until recently, this use of random

\footnotetext{
${ }^{5}$ See Steinman (1978), pp. 1-6 and Corson, Long, and Nichoison (1985), pp. 2-4.

${ }^{6}$ See Spiegelman, O'Leary, and Kline (1991), pp. xii-xiv, and Corson, Decker, Dunstan, and Kerachsky, p. 1.
} 
assignment to evaluate social programs has not been common in any Western country besides the U.S.

For two reasons, this paper focuses on reforms that have been evaluated using true experiments. First, experimental evidence, if properly conducted and interpreted, is likely to be the most convincing to social scientists and policy makers alike. Experimental evidence is easy to explain to policy makers, and the assumptions necessary for its validity are often weaker than those required in nonexperimental empirical work. ${ }^{8}$ However, experimental evidence can have important weaknesses. I will return to this point later. The second reason to focus on experiments is purely practical; the focus narrows the scope of the paper to a small group of reforms that can be adequately analyzed.

\section{EVALUATING THE EVALUATIONS}

The degree of success of the experiments can be measured in a number of dimensions. In most cases I will report the available statistics on whether the experiments achieved their objective of reducing weeks of benefits paid and costs. Because we might be concerned that a speedier exit from the UI rolls might result in a worse job placement, I also focus on claimants' subsequent earnings. Some other

\footnotetext{
${ }^{7}$ See Nathan (1988),

${ }^{8}$ See Hausman and Wise (1985) for a discussion of these issues. Of particular interest are the papers and comments in Chapters 3 and 5.
} 
6

outcome measures are analyzed below when available. Explicit analyses of the overall costs and benefits of the reforms are available for some of these experiments. These are discussed along with summaries of some of the costs and benefits that are available for the other experiments. I then discuss the long-term implications of adopting these programs, which may differ sharply from short-run analyses.

A number of conclusions can be drawn from the unemployment insurance experiments. The bonus experiments show that economic incentives do affect the speed with which people leave the unemployment insurance rolls. UI is not a completely benign transfer; it affects claimants' behavior. This is shown by the declines in weeks of UI receipt found for all of the bonus treatments, several of which were statistically significant. The experiments also show that speeding claimants' return to work appears to increase total earnings and hours worked following the claim, but the evidence is less strong. Furthermore, the experiments suggest that the rate of pay on the new job is not adversely affected by an earlier return to work. This would be an important finding and would imply that small changes in time out of work induced by small changes in UI are unlikely to appreciably affect the reemployment wage of claimants.

Despite these encouraging results, I do not believe that the experiments show that permanent adoption of a reemployment bonus would be beneficial to the UI system or society. The key diawback of the experiments is that they cannot account for the effect of a reemployment bonus on the size of the claimant population. A reemployment bonus makes the first trip to the UI office much more valuable for claimants as they become eligible for a large payment if they find a job soon. Such a payment is most valuable to 
someone who plans to start a job soon and may not currently believe filing for UI is worth the trouble. The UI experiments clearly show the effect of monetary incentives on the propensity to continue receiving benefits. There would likely be a similar effect on the propensity to file initially as the compensation for short UI spells increases. Changes in initial filing could eliminate or reverse the positive effects of a bonus.

The job search experiments test several alternative reforms which appear more promising. The six experiments try several different combinations of services to improve job search and increase enforcement of work search rules. Nearly all of these combinations reduce UI receipt, and have benefits that exceed costs. The treatments which mainly increase enforcement of work search rules have small but often statistically significant effects. The experiments which focus more on providing services induce much larger reductions in UI receipt, but at a higher cost of services per claimant. Nevertheless, these experiments have very favorable ratios of benefits to costs.

\section{The Bonus Experiments}

The cash bonus experiments made payments to UI recipients who found jobs quickly and kept them for a specified period of time. This section describes in turn the design of the experiments, the outcomes of the experiments, and then whether the results suggest that permanent adoption of a bonus program would be sensible. 


\section{A. The Experimental Designs}

Table 1 summarizes the main design characteristics of the four bonus experiments. The experiments differed along a large number of dimensions. These dimensions included the amount of the bonus payment, the period during which a person had to find a job to qualify for the bonus (the qualification period), and the period the individual had to remain at the new job to receive the bonus (the reemployment period). In addition to these elements, the point at which the offer of a bonus was made known to the claimant differed, as did the population of claimants offered the bonus, and the eligibility of people returning to their previous employer or hired through a union hiring hall.

The first bonus experiment in Illinois offered all claimants, regardless of their previous earnings or weekly benefit amount, a $\$ 500$ bonus. To put this dollar amount in perspective, it was about 4 times the average weekly unemployment insurance benefit. The qualification period was 11 weeks for all claimants and the reemployment period was 4 months. In other words, to receive a bonus a person had to start a job within 11 weeks of filing for benefits and keep that job for four months. The other experiments had different benefit amounts, qualification periods, and reemployment periods. The later experiments, particularly those in Pennsylvania and Washington, tried several different combinations of benefit amounts and qualification periods. Washington tried 3 different formulas for the bonus amount combined with 2 different formulas for the qualification period, for 6 different treatments in all. Pennsylvania also had 6 different treatments. Random assignment was also used to assign individuals to these alternative treatments. 
While the bonus amount was the same $\$ 500$ for all claimants in Illinois, in the three other experiments it was a multiple of a person's weekly benefit amount (which depends on their previous earnings). In Washington, the qualification period also varied across individuals within a treatment group, depending on their potential duration (which in turn depends on the stability of a person's earnings over the previous year). These formulas which determined the benefit amount and qualification period were the same within a treatment group, but differed across treatment groups. One of the treatments in the original Illinois experiment offered the $\$ 500$ bonus to employers who hired claimants. This treatment had a much smaller impact than the one which paid the $\$ 500$ to employees, and this approach was not tried in any of the later experiments.

Each of the experiments randomly assigned eligible UI claimants to either a control group which received existing benefits and services, or one of the treatment groups. However, 3 of the 4 experiments excluded several groups prior to this randomization. Generally, those with a definite recall date and those typically hired through a union hiring hall arrangement were excluded. The unemployment durations of these individuals were thought to be unlikely to be affected by a bonus. The experiments following the one in Illinois all excluded individuals recalled to a previous job. This exclusion eliminated the subsidy to temporary layoffs that would have been present if the Illinois bonus design had been permanently adopted.

There were some other aspects of the treatments that somewhat complicate comparisons across treatments and states. Several of the experiments combined the bonus offer with the provision of other services. The New Jersey experiment was a 
hybrid between a reemployment bonus experiment and a job search experiment. New Jersey had a mandatory job-search assistance (JSA) program which was part of all treatment groups (but not available to the controls). I discuss the bonus elements of the New Jersey demonstration here, while the job search treatments are discussed in Section 3. However, to assess the effects of the bonus alone, it seems most natural to compare the bonus with JSA treatment to the JSA only treatment. For some of the published statistics one can make such comparisons, but for other outcome measures one must make the comparison informally. Pennsylvania also tried a job search workshop, but it was optional and the participation rate was under three percent. Therefore, I follow Corson et al. (1991) and assume that we can ignore the effects of the workshop.

\section{B. Effects on Weeks of Benefits and Earnings}

Table 2 reports estimates of the effects of the four experiments on weeks of unemployment benefits received and measures of reemployment earnings. Reducing the weeks of UI received by claimants was an explicit goal of all of the experiments. I report the weeks of benefits received in the benefit year ${ }^{9}$ rather than dollars of benefits or weeks in the first spell of UI receipt because benefit year weeks are precisely measured, and are easier to compare across experiments. In all cases, I report the mean for the

The benefit year is the 52 week period beginning with the week the individual filed for UI benefits. 
treatment group in question minus the mean for the control group. ${ }^{10}$ This statistic provides an estimate of the effect of the bonus on the number of weeks of UI benefits received. When available, I aiso report the same statistic obtained after one accounts for the effects of individual characteristics in a regression analysis. These individual characteristics typically include age, sex, race, and other variables such as location in the state and recall expectations. The control group mean weeks of benefits and earnings are reported in the notes to Table 2.

Several of the evaluation reports overstate the case for using regression controls for individual characteristics in the estimates of experimental effects. As long as the randomization is done properly, comparisons of means are unbiased and probably more convincing to policy makers. The improved precision of the estimates with regression controls appears small in all cases in Table 2, which is expected given the small proportion of the variance in the dependent variable explained by the equations. ${ }^{11}$ Large differences between the estimates with and without regression controls should be taken as evidence that random assignment was not carried out properly.

The negative numbers reported in the first two columns of Table 2 indicate that the number of weeks of UI benefits received was lower for those who were offered a reemployment bonus. The bonus offers appear to have caused a decline in UI receipt in all of the experiments, though many of the declines are not statistically significant at

\footnotetext{
${ }^{10}$ The mean for a treatment group is the mean for all those assigred to the treatment group not just those who participate or receive a bonus. This method allows us to use the controls as a valid comparison group.

"For example, the New Jersey benefit year weeks equations has an $R^{2}$ of .064 .
} 
conventional levels. The Illinois claimant experiment had by far the largest effect and the one that is statistically the strongest. Mean weeks of benefits fell by over 1 week when individuals were offered $\$ 500$ for starting a job within 11 weeks of filing for benefits. The employer experiment in Illinois had a much smaller impact on weeks of benefits, and payments to employers were not tried in any of the later experiments. Some reasons for the differing results of the two experiments are mentioned in Section 5 below.

The three subsequent experiments, in New Jersey, Pennsylvania and Washington, all estimate much smaller effects of reemployment bonuses. In New Jersey, the jobsearch assistance (JSA) and bonus treatment has a large estimated effect of almost one week, and this difference from the control group is statistically significant. However, when one compares this treatment to the JSA only treatment, one sees that the estimated additional effect of the bonus is much smaller and only marginally statistically significant. In both Pennsylvania and Washington the estimated effects of the different bonuses on weeks of benefits are mostly small and of weak statistical significance. To put the magnitudes of the estimated effects in perspective, the average weeks of UI received in the benefit year by the control group ranged from 15 to 20 weeks in the different experiments. The effects of the bonuses cluster around one-half of a week, or about 3 percent of the average duration of receipt.

There is some tendency for the larger bonuses and those with a longer qualification period to have a larger effect, but this relationship is not strong. In both Pennsylvania and Washington, regressions were estimated to determine if there was any 
statistical evidence that the effects of the bonuses rose with either the bonus amount or the qualification period. In both experiments a higher bonus and longer eligibility period were associated with greater impacts, but neither effect was statistically significant. Each thousand dollars of a bonus was estimated to reduce UI receif. one-third of a week in Pennsylvania and almost one-half of a week in Washington.

Other measures of UI receipt, such as weeks in the first spell and dollars of benefits received, show a similar pattern of decreases by those offered bonuses. Overall, the experiments show the tendency of people to find a job more quickly if there are monetary incentives to do so. However, the evidence comes from the consistent negative values for the treatment minus control differences in weeks of UI receipt rather than from precisely measured effects of each treatment.

A key measure of the success of the bonus offers is their effect on claimant earnings. I focus on two distinct measures of earnings: weekly or quarterly earnings which is an indicator of the quality of the job; and total earnings during a period of several quarters after filing the UI claim which is largely determined by the number of weeks worked. If claimants are induced to find a job more quickly, the job they find inay be less desirable. I examine quarterly earnings because it is an easily quantifiable measure of the desirability of a job and it is available for all of the bonus experiments. The last column of Table 2 reports the estimated impact of the different bonus offers on quarterly earnings. As with the weeks of UI estimates above, I report the earnings of those who received the bonus offer minus the earnings of those in the control group. The reports on the different experiments did not use a common measure of earnings, so 
I have used what was available, supplemented by my own calculations and numbers obtained through private correspondence. ${ }^{12}$ The measures reported in Table 2 are intended to capture quarterly earnings after leaving the UI rolls. The measures are either earnings during the first full quarter after ending receipt of UI or earnings 3 or 4 quarters after first claiming benefits.

The estimated effects of the experiments on earnings are somewhat encouraging. The experiments show no statistically significant declines in earnings, and many of the bonuses offered to workers actually indicate no change in earnings or small increases. In Illinois the claimant experiment group has slightly higher earnings than the control group, but the difference is not significant. Treatment group earnings for the employer experiment are lower, but not significantly lower than the claimant experiment or control group. In New Jersey the difference in the change in earnings between the JSA only and the JSA plus bonus group is positive. In Pennsylvania there are slight increases in earnings for all treatment groups except for the "low bonus short qualification period" group where the hypothesis of no change in earning cannot be rejected. ${ }^{13}$ In Washington the estimates are that earnings fell somewhat, but the changes are statistically insignificant as they are for the other experiments.

\footnotetext{
${ }^{12}$ Paul Decker of Mathematica Policy Research kindly supplied quarterly earnings numbers for Pennsylvania.

${ }^{13}$ The inclusion of the job search workshop as part of the treatments may have affected these results somewhat, but as less than 3 percent of claimants attended the workshop the bias is likely to be small.
} 
Even if quarterly earnings on the new job were unchanged, an individual's total earnings after filing for UI might have increased if he or she worked more weeks. The bonus offers reduced weeks of UI received, but did this translate into an equivalent number of more weeks worked? Earnings data from three of the experiments, Illinois, New Jersey and Pennsylvania allow the examination of this hypothesis. ${ }^{\text {it }}$ All three experiments suggest increases in earnings in the $\$ 100$ to $\$ 200$ range which are consistent with this hypothesis. ${ }^{15}$ These figures can be compared to control group quarterly earnings which ranged from $\$ 2,517$ to 3,121 for the three experiments for which the numbers are available.

C. Other Outcomes

Several of the other objectives of the bonus experiments were not achieved. The New Jersey experiment attempted to target displaced workers who were implicitly defined as those at least 25 years old with 3 years of job tenure and without a definite recall date. These screens eliminated three-fourths of the claimants and selected a group that had 17.9 weeks of UI receipt on average compared to 15.1 for those not selected. While those selected are statistically different from those not selected, it is not clear these differences are large enough to merit special treatment. Furthermore, the

${ }^{14} \mathrm{I}$ examine labor earnings and thus exclude UI and bonus payments in these comparisons.

${ }^{15}$ See Meyer (1988), p. 39 for evidence on Illinois, Corson et al. (1991), p. 22 for New Jersey, and unpublished Pennsylvania tabulations. 
differential effect of the treatments on different groups should also be taken into account when targeting groups. While all of the experiments examined whether the bonuses had larger UI benefit and/or earnings effects on certain groups, no clear patterns emerged as to which groups responded the most to the treatments.

The Pennsylvania and Washington experiments sought to determine an optimal bonus amount and qualification period. Optimal is not precisely defined in the evaluations, but can be taken to mean a treatment which maximizes net benefits in a cost/benefit analysis. Each experiment tried six different treatments with different benefit amounts and qualification periods. The small number of observations per treatment caused the impacts to be imprecisely measured and makes comparisons among the treatments difficult. As mentioned above, regression models which assumed a linear relationship between the outcome measures and the benefit amount and qualification period also yielded imprecise coefficients. Thus, the imprecision of the results makes the design of an optimal offer impractical.

D. Analyses of Costs and Benefits

To assess whether a reemployment bonus is a desirable policy to adopt permanently, we need an overall accounting of the costs and benefits of such a program. The reports on the experiments have cost-benefit analyses usually undertaken from a number of perspectives. These perspectives usually include that of the UI system, government as a whole, and society in general. I believe that the cost-benefit analyses in 
the published reports are easily misinterpreted, as they all ignore likely effects of a reemployment bonus on the inflow to unemployment and the UI claims pool as discussed in Section 2.E below. Nevertheless, for completeness I summarize their results.

The cost-benefit analyses from different perspectives differ as to what is included among the costs and benefits. From the perspective of the UI system, the costs of a bonus program are the bonus payments and administrative expenses. ${ }^{16}$ The benefits are the reduced UI payments. From the perspective of the government as a whole, the benefits also include tax revenues on any earnings increases. A societal perspective ignores bonuses and UI payments as they are just transfers between the government and individuals. The costs are the administrative expenses, and the benefits are any increases in claimants' earnings and fringe benefits. This is the procedure that is followed in the evaluation of most of the experiments. The evaluations do not try to quantify work costs such as childcare, or the leisure value of time out of work which would enter a complete accounting. ${ }^{17}$

I should emphasize that the cost-benetit analyses make several strong assumptions. They generally assume that workers who take a job more quickly do not displace other workers from those jobs. They assume that the short run response by current UI claimants is a good estimate of the long run response to a permanent bonus program.

\footnotetext{
${ }^{16}$ This perspective is that of a narrow administrator who wants to insure as large a UI budget surplus as possible without altering taxes.

${ }^{17}$ One should also note that these are not true economic measures of changes in welfare such as compensating or equivalent variation. Thus, they ignore changes in deadweight loss from tax distortions if payroll taxes change, for example.
} 
Lastly, they assume that there is no new entry into the pool of UI claimants after the financial rewards for a short UI spell have increased.

The Illinois claimant experiment sharply reduced UI payments without paying a large number of bonuses. Consequently, both the UI system and the total government cost-benefit analyses were strongly favorable. Total earnings also increased, so that a societal level cost-benefit analysis was also favorable. In New Jersey, there were only small differences between the bonus with the JSA, and JSA only estimates for all costbenefit measures. Thus the additional benefits of the bonus beyond that of the JSA were essentially zero. In Pennsylvania, the UI system lost a small amount in 4 of 5 treatments, all government was about even, and society tended to benefit due to increases in worker earnings. In Washington, most treatments had costs to the UI system and to all government that exceeded benefits. ${ }^{18}$ However, the increases in worker earnings caused 5 of 6 treatments to have positive net societal benefits.

These cost-benefit analyses should not be surprising given the UI benefit and earnings responses described above. The Illinois experiment was a success from all perspectives because it elicited a large reduction in weeks of UI benefits claimed. In the other experiments, there were small responses of weeks of benefits to the bonuses, leading to small or negative effects on the UI system or total government. Because total employee earnings, when available, increased in all of the experiments, there was a net societal gain from the bonuses.

${ }^{18}$ The Washington earnings changes are not calculated using earnings estimates. Rather, weeks worked are assumed to go up one for one when weeks of benefits go down. In the other experiments, measured earnings after filing for UI go up. 


\section{E. Interpreting the Long Run Effects of Bonus Offers}

It is unclear whether the experimental impacts of bonuses just described can be directly applied to a permanent program. There are at least three sources of uncertainty. First, if one group of individuals is encouraged to go back to work early, they may gain employment at the expense of others who are unable to get jobs. Second, with a permanent program a different fraction of eligible claimants might apply for the bonus causing a change in the costs of the bonus offer. Third, by increasing the financial reward for short UI spells, a permanent bonus would probably increase the number of people unemployed between job changes and increase the number of UI filers. These three arguments imply that the simple cost-benefit analyses in Section 2.D overstated the benefits of a reemployment bonus. I will discuss displacement, participation rates, and entry effects in turn.

Displacement occurs if by taking jobs more quickly, those eligible for a bonus reduce the number of job vacancies available to other unemployed workers. This possibility has been mentioned by a large number of researchers. ${ }^{19}$ The easiest way to understand this possibility is to consider a situation where the number of jobs is fixed. If such displacement occurs, the cost-benefit analyses have overstated the net benefits of

${ }^{19}$ See Johnson (1979), Solow (1980) and Bassi and Ashenfelter (1987) for discussions of displacement in training programs, and Atkinson (1987) for displacement and UI. Also see some of the reports on the experiments, in particular Spiegelman and Woodbury (1987), pp. 8.8-8.10, Corson, Decker, Dunstan, and Kerachsky (1991), pp. 156157 and Spiegelman, O'Leary and Kline (1991), pp. 230-231. 
bonuses, because the gains to those eligible for a bonus come partly at the expense of longer unemployment for other workers. Theoretical examinations of displacement have led to ambiguous results: some theories suggest no displacement, while equally plausible theories suggest near complete displacement. ${ }^{20}$ In the end, the issue must be settled empirically. Unfortunately, we have little direct evidence from any source to determine the importance of displacement. ${ }^{21}$ However, some indirect evidence of little or no displacement comes from the literature on immigration. This literature suggests that large increases in the number of immigrants looking for jobs has little effect on low-wage natives. ${ }^{22}$ Other indirect evidence that suggests some displacement comes from work on cohort crowding effects. This literature finds that larger cohorts of workers tend to have lower employment rates and receive lower wages. ${ }^{23}$ As current evidence on the importance of displacement is inconclusive, the possibility of displacement remains as a caveat on the results in the paper.

The issue of participation also affects the long run net benefits of a reemployment bonus. A substantial portion of those eligible for a bonus in each of the experiments did not fill out the required paperwork to receive the money. The Illinois claimant experiment estimated that 55 percent of eligible claimants received the bonus, in

r See Davidson and Woodbury (1991b) for a simulation study of the displacement effects of a reemployment bonus.

${ }^{21}$ Bassi and Ashenfelter (1987) state that there have been no formal analyses of this issue. Levine (1991) has recently examined displacement for UI recipients, but additional research in needed before strong conclusions can be made.

rSee Card (1990) and the references given there.

${ }^{23}$ See Bloom, Freeman and Korenman (1987) for example. 
Washington the estimated takeup rate was 66 percent, and in Pennsylvania a lower bound was estimated to be 65 percent. If all of these additional claimants received a bonus, the UI system and total government cost-benefit analyses would be much less favorable. However, it is unclear whether long-run participation would be any higher given the low participation rate for many permanent social programs. ${ }^{24}$ The issue of incomplete participation is discussed further in Section 5 .

The last reason to pause before extrapolating the experimental results to a permanent program is the possibility that a bonus would affect entry onto the UI rolls. ${ }^{25}$ The experiments estimate one important behavioral response to financial incentives, but implicitly set several other behavioral responses to zero. A bonus offer substantially raises the reward for initially contacting the UI office for someone who knows he will begin a new job within the qualification period, and raises the reward by something less for all others. ${ }^{26}$ Recall (from Table 1) that the bonus amounts ranged from 3 to 10 times the weekly benefit.

A permanent bonus program may have larger costs than the temporary experiment for three reasons. First, the currently unemployed who do not file could respond to the increased incentives to file for UI benefits. Second, those currently not unemployed but changing jobs could start work slightly later and file for UI benefits.

\footnotetext{
${ }^{24}$ See Moffitt (1983) for participation rates in 3 programs that range from 38 to 69 percent.

${ }^{25}$ The following paragraphs are an updated version of a section of Meyer (1991).

${ }^{26} \mathrm{~A}$ claimant would also need to know that he would hold the new job until the end of the reemployment period.
} 
And third, firm layoff policies could respond to the increased compensation for short UI spells. Using results from previous work as well as new evidence, the following paragraphs document that all of these responses are potentially large. ${ }^{27}$

First, those who become unemployed under existing incentives, but do not file, could respond to the new incentives. Blank and Card (1991) estimate that only 68 percent of those eligible for UI in the Current Population Survey (CPS) during 1982-87 and 83 percent of household heads eligible for UI in the Panel Study of Income Dynamics (PSID) during 1980-82 received benefits. ${ }^{28}$ Additional evidence comes from 1989 and 1990 supplements to the CPS which contained questions about UI application, receipt, and reasons for nonreceipt (see Vroman (1991)). Only 37 percent of the unemployed applied for UI. Of those that did not apply, only 53 percent said they didn't think they were eligible. ${ }^{x-9}$ Putting these two numbers together suggests that 45 percent of those eligible may not apply for benefits. The most frequent reasons given for not applying are: expected to get another job soon (29.7\%), don't know (18.5\%), too much work to apply (5.9\%), didn't know how to apply (5.7\%), and too much like charity $(5.2 \%)$. The vast majority of these reasons do not sound as if they would preclude monetary incentives from encouraging a claim. In summary, these data sources indicate

\footnotetext{
${ }^{2}$ The argument here is similar to that in Moffitt (1992) who argues for the possibility of similar entry responses in the context of welfare and training programs.

"See Blank and Card (1988) for a discussion of the differences between the CPS and PSID numbers. The samples of unemployment spells in the two surveys differ along several dimensions.

${ }^{x}$ The other main reasons for not applying were "expected to get another job soon" (14 percent), "don't know" (11 percent) and "other" ( 9 percent).
} 
that a large number of the currently unemployed could respond to additional incentives to file for UI.

There is some evidence that UI filing rates depend on the financial rewards for filing. When explaining aggregate state/year data on UI receipt rates, both Corson and Nicholson (1988) and Blank and Card (1991) find a large and highly significant coefficient on the fraction of earnings replaced by UI. ${ }^{30}$ Using individual data from the Youth Cohort of the National Longitudinal Survey, Gritz and MaCurdy (1989) find substantial effects of the level and duration of benefits on the probability of UI receipt conditional on unemployment. The results in Meyer (1992) are also consistent with a large effect of benefits on the take-up rate. I find that claims increase disproportionately among individuals who experience a benefit increase in New York State. Earlier evidence in Meyer (1989) suggests little effect. Another factor to consider is that many people wait a few weeks before filing for benefits. More than one-fourth of those who eventually file take at least four weeks to do so. ${ }^{31}$ The increased incentives to file promptly would tend to increase the number of weeks of UI received.

Second, those who currently change jobs without an intervening spell of unemployment $^{32}$ could become unemployed for a few weeks, start work slightly later,

\footnotetext{
${ }^{30}$ When Blank and Card estimate a similar relationship on PSID individual data however, they do not find a significant relationship.

${ }^{31}$ This figure is for Idaho, Missouri, New Mexico, Pennsylvania and South Carolina, and comes from data described in Meyer (1989).

${ }^{32}$ I was able to find three estimates of the frequency of job changes without an intervening spell of unemployment. Mincer (1991) finds that over 30 percent of job changes do not involve unemployment, Gottschalk and Maloney (1985) report 24 percent for a sample of involuntary separations which includes fires, and Gibbons and Katz
} 
and file for UI benefits and the bonus. Continuous Wage and Benefit History (CWBH) data can be used to determine what fraction of job separations could potentially become UI claims. Data reported in Table 6 of Meyer (1991) indicate that in 6 states the percentage of individuals with separations that are monetarily eligible (i.e. have sufficient base period and high quarter earnings) for UI varies from 55 to 74 . Of those eligible, only 10 to 32 percent (depending on the state) actually file for UI benefits. Some of the 68 to 90 percent who do not file are nonmonetarily ineligible due to quitting or being fired for misconduct, but a large percentage could be eligible. This suggests that a large number of individuals could choose to have short unemployment spells between jobs if the reward for the first week of benefits increased by a factor of three to ten (see Table 1).

Anderson and Meyer (1992) provides the most direct evidence on the effect of benefit generosity on the UI claims rate of people who change jobs, but who do not necessarily become unemployed. Using CWBH data on over 80,000 separations in six states, we find a pronounced effect of the level of UI benefits on the probability of receiving UI. In addition, several authors find positive effects of benefits on layoff rates. These results lead to the third behavioral response.

Firms will probably change their layoff policies in response to the large increase in compensation for short UI spells provided by a reemployment bonus. Brechling (1981), Clark and Summers (1982), and Topel (1983) find large and statistically significant effects

(1991) give 14 percent for displaced workers. 
of higher UI benefits on the probability of entering layoff unemployment. ${ }^{33}$ The approaches of Brechling and Topel are particularly designed to capture the incentives firms face when considering layoffs. Their results suggest that higher compensation for short UI spells will make layoffs more attractive to firms. While much of the effect of benefits is probably on layoffs that are initially thought to be temporary, in about onethird of such layoffs the worker is not recalled. ${ }^{34}$ Therefore, even if recalled individuals cannot receive a bonus, there will probably be an effect on layoffs as part of the compensation package in cyclical and seasonal industries increases. In addition, if we increase the compensation for laid off workers, it makes jobs with a high probability of layoff more attractive. The incentives will subsidize the expansion of cyclical and seasonal industries, also tending to increase layoffs and unemployment, ${ }^{35}$ While changes in the take-up rate would only tend to increase UI payments, increases in claims between jobs and increased layoffs would raise unemployment as well.

It is possible that part of the experimental impacts of the treatments were due to Hawthorne effects. The term Hawthorne effects refers to responses that come from the act of experimentation itself rather than the intended treatment. ${ }^{36}$ For example,

\footnotetext{
${ }^{33}$ Topel interacts benefits with the fraction of benefits that a firm will not pay through experience rating.

${ }^{34}$ See Katz and Meyer (1990).

${ }^{35}$ See Deere (1991) for empirical evidence on UI induced industry cross-subsidies, expansion of high layoff industries, and unemployment.

${ }^{36}$ The term Hawthorne effects comes from experiments conducted at the Hawthorne plant of the Western Electric Company in Chicago between 1924 and 1933. The first of the experiments appeared to show that changes in the level of illumination resulted in increases in worker productivity and job satisfaction whether the lighting was increased or
} 
claimants may have reduced their receipt of UI because they were under study per se, rather than because of the bonus offer. This explanation is not precise so, it is hard to rule it out. However, Hawthorne effects are a less plausible explanation if larger bonuses tended to produce larger responses and if groups that were expected to be more responsive to a bonus did respond more. Such evidence would suggest responses to the character of the treatment rather than the act of experimentation per se. There is only weak evidence of this form. As mentioned above, there is a tendency for the larger bonuses to elicit greater responses, but this tendency is not pronounced. There is also little evidence of a larger response by low earnings individuals to the fixed $\$ 500$ bonus in Illinois (see Meyer (1991)).

\section{F. Additional Comments}

While the initial reaction of policy makers and academics to the bonus experiment idea was very positive, I believe the initial optimism is fading. With time we can see more clearly the weaknesses of the experiments as a guide to the viability of a permanent bonus program. The initial results from Illinois were so striking that additional bonus experiments were tried. If the Illinois experiment had produced weak results, the idea probably would not have been repeated.

The large magnitude of the Illinois responses is still puzzling. Davidson and Woodbury (1991a) have argued that the availability of extended benefits during the first

decreased. For a critical examination of these experiments see Franke and Kaul (1978). 
part of the Illinois sample period interacted with the bonus to produce larger effects. They find larger differences between the treatments and control groups during the period that extended benefits were available. However, the Illinois claim duration effects were still larger than the others during the period when extended benefits were not available. Other possible explanations include the state of the macroeconomy (the unemployment rate at the time of the experiments was by far the highest in Illinois) or that Illinois allowed employees recalled by their former employer to receive the bonus.

\section{The Job Search Experiments}

The job search experiments tried several different combinations of improved provision of job finding services and increased enforcement of the job search requirements for the receipt of UI. This section describes in turn the design of the experiments, the outcomes of the experiments, and then whether the results suggest that permanent adoption of an expanded job search program would be sensible.

\section{A. The Experimental Designs}

Table 3 summarizes the main design characteristics of the six job search experiments. Each of the experiments was slightly different and several of the experiments had more than one treatment. The main differences between the treatments were the job finding services provided and when a claimant was required to report to the 
UI/ES offices. The experiments also differed according to when the new services or requirements were provided and whether some claimants were excluded from the demonstration.

The job finding services provided in the experiments included materials on job openings and more job referrals. In several experiments, Employment Service personnel urged claimants to search in areas that they had overlooked or avoided. The Washington and Minnesota experiments emphasized more personalized or individually tailored assistance. The two Nevada experiments and the Minnesota project emphasized more intensive and higher quality delivery of existing services. These three experiments also insisted that all Unemployment Insurance and Employment Service contacts be provided by the same person or pair of individuals (one from UI, one from ES). Two of the experiments, the Nevada Claimant Employment Program and the New Jersey experiment, also provided training or relocation assistance. These services were used by so few individuals that an adequate evaluation of them cannot be made. Two other experiments, Charleston and Washington, required that one of their treatment groups attend a seminar on how to find a job.

An important element of several of the experiments was more frequent checks of claimant eligibility, and additional required visits to the UI or ES offices to maintain UI eligibility. The Nevada Claimant Placement Program required weekly interviews and eligibility checks, Charleston required a different number of in depth interviews depending on the treatment group, and New Jersey required periodic contacts with the Employment Service. This combination of additional services and tightened eligibility 
checks makes it difficult to determine what aspects of the experiments induced the changes in outcomes below.

One of the treatments in Washington tried the opposite approach of requiring fewer checks of claimant job search activities. This exception reporting treatment was based on the honor system, meaning that UI payments were sent to claimants until they indicated that they were no longer eligible, i.e. had returned to work. Claimants were instructed to make an active job search, but no job search services were provided and no reporting of work-search contacts was required.

The experiments differed according to when claimants were first contacted and told of their obligations or opportunities. Some experiments excluded from the population examined certain groups such as those on temporary layoff. ${ }^{37}$ The experiments that delayed contacting claimants or excluded others generally did this to exclude certain individuals who did not need to report to the Employment Service or were thought to be unlikely to benefit from the job search services.

B. Effects on Weeks of Benefits and Earnings

Table 4 reports estimates of the effects of the six job search experiments on weeks of unemployment benefits received and measures of reemployment earnings when available. See Section $2 \mathrm{~B}$. for discussion of the reasons for using these outcome

\footnotetext{
${ }^{37}$ In all experiments except Re-Employ Minnesota, the exclusions took place prior to random assignment or were applied to both treatment and control groups.
} 
measures. The mean for the treatment group in question minus the mean for the control group provides an estimate of the effect of the treatment on UI receipt. When available, I also report the same statistic obtained after one accounts for the effects of individual characteristics in a regression analysis.

Three of the experiments show large declines in weeks of UI benefits received by the treatment group. These experiments, two in Nevada and one in Minnesota, show statistically significant average reductions in weeks of UI of 1.6 to 4.3 weeks. These experiments emphasized higher quality delivery of existing services and required claimants to return to the same ES/UI team for all contacts. Unfortunately, these experiments have the least complete evaluations and suffer from some design weaknesses that I discuss later. We have no estimates of earnings impacts for any of these three experiments. Standard errors on the weeks of UI effects were not reported for two of the experiments, so I have approximated them using the reported sample sizes and a standard deviation of weeks of 10 , which is slightly larger than the average from the other experiments. For the second Nevada experiment, I have reported changes in weeks of UI for two samples: including and excluding trainees. The treatment group was offered access to a training program, though few enrolled. As these individuals were expected to have long UI durations, including them probably biases the effect of the experiment towards zero; excluding them probably has the reverse effect. Fortunately, the results are qualitatively similar ( 1.6 versus 2.1 weeks) either way. Overall, the Minnesota and two Nevada experiments seem the most promising, but they require more study because their evaluations are incomplete. 
The three other job search experiments had more modest effects on weeks of UI received. Charleston, New Jersey and Washington all show reductions of about one-half of a week in UI receipt from the more intensive services and oversight. Several of these effects are statistically significant or nearly statistically significant. These impacts are about the same size as those of the bonus experiments. The Washington exception reporting treatment that did not provide any services and reduced the oversight of claimants was associated with a large and statistically significant 3.34 week increase in weeks of UI received. As was the case for the bonus experiments, regression controls have almost no effect on the point estimates or their standard errors.

Earnings impacts are also available for two of these three experiments.

The earnings estimates agree with the earlier bonus results in that an early exit from the UI rolls does not decrease quarterly earnings. The full year earnings results from New Jersey (not reported in Table 4) as well as the Washington changes are of a magnitude that suggests the one-half week reduction in UI receipt is associated with one-half week more of work. However, neither of the estimates is significantly different from zero. There does not appear to be a symmetric decline in earnings for the Washington exception reporting treatment which removed almost all oversight by the Employment Service and increased UI receipt by 3.34 weeks. These additional weeks of UI receipt do not seem to have been translated into fewer weeks of work, as total earnings in the year were only slightly lower while hourly earnings over the year were insignificantly higher than the control group. While this treatment did not affect earnings during the year after 
claim, it did significantly increase the probability of a worker returning to the same employer or industry.

C. Enforcement of the Work Search Requirements

One of the goals of the job search experiments was to reduce abuse of the UI system by claimants who do not search for work as required. This section reports the effects of the experiments on the enforcement of work search rules. In four of the six job search experiments, administrative measures of enforcement such as denials of benefits increased significantly.

These four experiments required claimants to make additional trips to the Employment Service and failure to report could result in denial of benefits.

The experiments differ whether the increased denials ${ }^{38}$ were due to failure to report or to better enforcement of the work search rules. In Charleston it appears that better enforcement of work search was more important, while in New Jersey and Washington an increase in denials for failure to report was the only significant change. ${ }^{39}$ It is possible that those failing to report would have been denied for work search reasons, but the results suggest that part of the reduction in UI receipt in these experiments came

\footnotetext{
${ }^{38}$ Some of the experiments reported measures of enforcement other than denials. For example, Washington reported conditional payments (payments made pending resolution of an enforcement issue).

${ }^{39} \mathrm{~A}$ hazard model analysis in the Washington report analyzes the timing of the effects of the work search services. It suggests that the shorter durations of UI receipt are due to the costs of appearing at the UI office.
} 
from the additional costs imposed on claimants. In all cases however, denials per se would account for a small fraction of the decline in weeks of UI received. If increased enforcement was responsible for most of the decline in UI receipt, the decline must have come from indirect effects of tighter enforcement such as deterring violations of worksearch rules.

In the second Nevada experiment (the NCEP) and in Minnesota there was no attempt to impose more requirements on claimants or increase compliance with work search rules. In Nevada, enforcement appears to have been unchanged or even fallen. ${ }^{40}$ Nevertheless, these two experiments were two of the three most successful in terms of reduced weeks of UI receipt. The main reason for their success appears to be the increased job search services provided.

The Washington exception reporting treatment provides some evidence of the effects of changes in the opposite direction, i.e, reducing reporting requirements. UI duration increased over 3 weeks when this treatment had claimants notify the UI office when they had found a job and did not require the reporting of work-search contacts. It is unclear whether this increase indicates that claimants were slow in notifying the UI office that they had found a job, or that eliminating the work-search reporting requirement actually reduced search effort, or just reduced disqualifications for weeks without search. As total earnings did not fall, it seems likely that the change in requirements did not reduce search effort.

\footnotetext{
${ }^{+0}$ The number of disqualifications was slightly lower for the treatment group than the control group.
} 
D. Job Searches, Referrals, and Placements

Four of the six job search experiments generated large increases for the treatment groups in measures of job search assistance such as job searches, referrals, placements snd counseling. The three experiments with the largest reductions in weeks of UI were among these four. The experiments generating large increases in services were the two Nevada experiments, Charleston, and Minnesota. In all of these experiments referrals to new jobs or placements more than doubled. At the other extreme, placements and referrals tended to be lower for the treatment groups in Washington, and in New Jersey the treatment groups received counseling but only modest increases in job referrals.

E. Analyses of Costs and Benefits

To assess whether a job search program is a desirable policy to adopt permanently, we need an overall accounting of the costs and benefits of such a program, as we did for the bonus experiments in Section 2.D. Except for the New Jersey experiment, the costs of the job search treatments were always low compared to the savings in UI benefits. Therefore, the UI system and total government benefitted from the programs. ${ }^{41}$ The benefits of the job search experiments tended to exceed costs by a

\footnotetext{
${ }^{41}$ In the New Jersey JSA only treatment UI system broke even and total government gained, while the JSA and training treatment had higher costs than benefits.
} 
wide margin. For example, in both the Nevada CEP and Minnesota the costs of the extensive additional services was only about half of the savings in UI benefits.

Societal level cost benefit analyses compare the administrative expenses of the experiment to the changes in claimant earnings. Unfortunately, earnings are only available in New Jersey and Washington. With the exception of one of the treatments in Washington, the results are consistent with decreases in weeks of UI being associated with equal increases in weeks worked. However, I should emphasize that most of the estimates of earnings impacts are not precise. If we are willing to assume this relationship holds for the other experiments, societal level cost benefit analyses would be strongly favorable for all of the job search experiments.

\section{F. Interpreting the Effects of the Experiments}

A key advantage of the job search approach to UI reform is that it is unlikely to increase entry into the pool of UI claimants. Unlike a reemployment bonus, job search assistance does not increase the incentives to file for UI if one already has a job lined up or expects to have a short spell. The possibility remains that those encouraged to find a job quickly will do so at the expense of others who are displaced by those workers.

However, to the extent that job search assistance improves the matching of workers and jobs, displacement may be less important. In addition, several of the experimental treatments led claimants to use the employment service more intensively, It is an important unresolved question as to whether this will draw down the quality and quantity 
of available job listings for others. Alternatively, it might induce employers to list more jobs with the ES as the number (and possibly the quality) of potential applicants grows.

It is possible that part of the experimental impacts of the job search treatments were due to Hawthorne effects if claimants responded to being in an experiment per se rather than the intended treatments. Hawthorne effects may be more plausible for the job search experiments than the bonus experiments because they involved repeated contact with claimants which the bonus experiments did not have. As mentioned above in Section 2 E., the imprecision of this hypothesis makes it hard to rule out completely. However, with the job search experiments there is stronger evidence that more intensive treatments produced larger responses, and treatments which were expected to increase UI receipt did so. The most intensive treatments were in the two Nevada experiments and Minnesota which also had the largest UI duration responses. The intensity of these treatments is indicated by the descriptions of the services, the large effects on referrals and placements, and the large administrative expenses per claimant. Other experiments such as New Jersey and Washington had small or no effect on service provision, and Charleston and Washington administrative expenses were extremely low because few services were provided. Washington also had two treatments which could have been expected to have no effect or increase UI receipt, and the results supported this. Thus, the pattern of the responses in the job search experiments is not consistent with Hawthorne effects being the main cause.

A potentially more important problem with several of the job search experiments is that the job service personnel were not likely to be representative of the entire pool of 
service providers. I will focus my comments on the experiments with largest UI responses: the Nevada experiments and Minnesota. In the first Nevada experiment, the treatment group received assistance from four two-person teams while, in the second experiment, they received assistance from two two-person teams. If job service personnel differ substantially in their ability to assist claimants, a sample of 2 or 4 is not iarge enough for such differences to average out. The outcome differences between treatment and controls may be partly a measure of the personnel's ability rather than the effect of the services provided. The Minnesota treatment group was assisted by 18 volunteers. The use of volunteers introduces the possibility that these service providers were different from those for the controls, and that the resuits from the experiment are not generalizable to all claimants and personnel. The results in Minnesota were very similar across UI/ES office, so it does not appear that personnel differences were of crucial importance.

Additional aspects of the experimental designs of the second Nevada experiment and especially the Minnesota experiment should cause us to interpret the results with caution. In the second Nevada experiment, the randomization was done using digits of the social security number that were not purely random. About 200 ciaimants with low social security numbers were included in the control group accidently. From comparisons of means of the treatments and controls, it appeared that these observations were Jdisproportionately older males. 120 older maies were excluded from the control group to compensate, but once random assignment was compromised, we cannot be sure that the treatment and control groups were completely comparable. 
The comparability of the treatment and control groups in Minnesota is probably a greater concern. The control group includes individuals with separation issues that would lead to an administrative hearing. These individuals indicated when applying for UI that their reason for leaving their last job was that they quit, were discharged, were on strike, etc. Tabulations from Minnesota indicate that these individuals were 31 percent of the control group. If these individuals had much longer spells, they would account for some part of the difference between the treatment and control mean weeks of UI receipt.

\section{Comparisons with Other Experimental and Nonexperimental Evidence}

One can compare the results of these UI experiments with those from other social experiments. There is a large experimental literature on the effects of job search assistance and other types of training on welfare recipients and other disadvantaged people. One of the main conclusions of this literature is that job search assistance appears to increase earnings and be cost-effective (see Gueron and Pauly (1991) and LaLonde (1992)). The evidence from the UI job search experiments supports this conclusion as the UI job search experiments are cost effective, and there is weak evidence that earnings increase.

The UI job search experiments do not show a clear pattern of larger effects for certain groups. While women seem to benefit more than men from job search assistance provided in other contexts, there is not a clear pattern of gender differences here. 
However, in four of the six experiments women have larger estimated changes in weeks of UI receipt than men. The reverse holds in the Charleston and Nevada NCPP experiments.

One can also compare the results of the UI experiments to nonexperimental evidence. While the bonus experiments show that monetary incentives affect job-finding rates, this was also evident from the long literature on UI and unemployment durations (see Meyer (1989) and the references there). This literature has assessed the effects of UI benefits on unemployment spells and reemployment earnings. To perform these studies, there are many differences in benefits across states, within states, and over time that are easily quantifiable. To evaluate the employment service, there are few quantifiable differences between state systems that one can use to estimate effects on unemployment durations or earnings. The job search experiments provide evidence that is difficult, if not impossible, to obtain from nonexperimental sources.

To estimate the effects of the employment service referrals one needs a group to compare to those who receive referrals. An appropriate comparison group is generally not available. The decision to use the employment service is typically made by a worker and cannot be considered to be independent of that worker's observable and unobservable characteristics. In addition, if one examines the effect of ES referrals, biases would result if ES employees select registrants to refer based on characteristics that the researcher does not observe. Such selection would occur if ES employees select the best registrants to refer to make ES performance look favorable. A further complication arises because the use of the service takes place over time. The 
unemployed typically use it only after they have unsuccessfully tried other means of finding work. Thus, simple comparisons between those that do and do not use the ES spuriously indicate that the ES lengthens their unemployment durations. ${ }^{42}$

Various authors have tried to overcome this lack of an appropriate comparison group in studies of the effectiveness of the employment service. ${ }^{43}$ One of the most convincing papers is Johnson, Dickenson and West (1985). They try multiple approaches to finding an appropriate group to compare to those who receive ES referrals. However, there still are important differences between those referred and those not referred. In particular, it appears that people use the ES after they have unsuccessfully searched using other means. While this paper is an excellent nonexperimental study, the results are not completely convincing because we do not know why certain individuals are referred by the ES and others are not. Furthermore, overall estimates of the impact of the ES do not indicate how the ES can be improved. As this kind of information can be obtained from the job search experiments, 1 believe there is an important role for experimentation in evaluating job finding services.

${ }^{42}$ See Katz (1980) who explains this argument in detail.

${ }^{43}$ See Katz (1980), Johnson, Dickenson and West (1985), Osberg (1988), and Romero, Cox and Katz (1991). 
41

\section{Other Uses of the Experimental Data}

A literature has emerged that uses the data from the UI experiments to test economic theories. This use of the experimental data may be an important side benefit of the bonus experiments. The experiments provide exogenous variation in some of the parameters of the UI system, allowing various theories to be examined.

A series of papers tests search theory and labor supply models of unemployment. In a labor supply model, unemployment is treated as leisure and individuals maximize over income and leisure. ${ }^{4}$ The effects of a bonus offer is captured in this model by an upward shift in the budget constraint by the amount of the bonus over the range of unemployment that makes an individual eligible for the bonus. On the other hand, a search theory model summarizes a bonus through an increase in the value of a job during the period of bonus eligibility. The higher job value increases search intensity and lowers the reservation wage during the period of bonus eligibility. ${ }^{45}$

Meyer (1991) examines several predictions of labor supply and search models when applied to the Illinois experiment. Both theories imply higher job finding rates during the period of eligibility for the bonus. They also imply increases in the rate of job finding just prior to the end of the bonus eligibility period. Lastly, both models can be shown to imply a larger effect of a fixed $\$ 500$ bonus on lower wage individuals. The data

${ }^{4}$ See Moffitt and Nicholson (1982) for an example of such a model.

${ }^{45}$ See Mortensen (1987), Levine (1991) and Anderson (1992) for examples of models of this form. 
show clear support for the first hypothesis, but only weak support for the other two. In Pennsylvania it appears that there was a small increase in job taking just prior to the end of eligibility. ${ }^{46}$ Thus, the Illinois and Pennsylvania data only weakly indicate the increases in job finding predicted by labor supply and search theories.

There is littie evidence to distinguish between the two theories of unemployment. However, the absence of a large number of people taking jobs at the end of the eligibility period is a rejection of the labor supply theory in its strictest form. Such a theory would predict many individuals to locate at the corner of the budget set located at the end of the eligibility period. The small and often positive (though insignificant) effect of the bonus offers on reemployment earnings supports the labor supply theory where the wage is fixed. But the earnings numbers are also consistent with most of the adjustment to the bonus offer in a search model coming through search intensity rather than the reservation wage.

Levine (1991) tests whether a simple search theory model fits the data from the Illinois and New Jersey bonus experiments. He finds that it is difficult to reconcile the results of the two experiments using these models, and that the degree of wage variability is hard to explain. Given the large differences between the bonus responses in the two states (see Table 2), it is not surprising that it is difficult to reconcile the data from the two samples.

${ }^{46}$ One would not expect similar behavior in New Jersey since the bonus decreased to zero at the end of the eligibility period. An examination of this issue is not possible in the published Washington data since the length of the eligibility period varied across individuals. 
Anderson (1992) examines the rates of recall and new job finding in the New Jersey experiment. This work provides a nice test of a search model where a person may be recalled to a previous job. We would expect that an individual would revise downward his expectation of being recalled as his unemployment spell continues. This type of a model was proposed by Katz (1985). Anderson finds that the bonus offer and the job search assistance workshop have little effect on the recall rate, as we would expect since the experiment did not allow recalled workers to receive a bonus. She further finds that the job search workshop seems to have much of its effect through convincing people who initially expect to be recalled to consider searching for a new job. She also finds a declining negative effect of recall expectations on new job finding, which agrees with Katz's model of worker updating of recall expectations. These results and those for the other job search experiments suggest that the treatments may reduce constraints faced by the unemployed. The provision of job finding information in the form of referrals and suggestions of search areas and methods appears to reduce unemployment durations.

Besides their implications for theories of unemployment, the bonus experiment results, in particular the low takeup rates, agree with past findings of low participation in many social insurance programs. As indicated above, the takeup rates for the bonuses ranged from 55 to 66 percent. This omits the employer experiment in Illinois where the takeup rate was a minuscule 12 percent. These numbers provide further evidence of stigma or transaction costs associated with government grants. It is surprising that there would be such low participation given that UI recipients had already overcome any 
stigma or transaction costs of initially applying. The receipt of a bonus typically only required filling out 1 or 2 forms, yet this often was not done.

The low participation in the Illinois Employer Experiment (where the employer received the $\$ 500$ bonus) is the subject of an article by Donohue (1989). He argues that comparisons of the Employer and Claimant Experiments in Illinois provide a test of the Coase theorem. In its simplest form, the theorem states that who receives the bonus payment should have no effect on the outcomes of the experiment, such as the changes in unemployment duration or earnings. The results of the experiment clearly indicate that it did matter who received the payment. While transaction costs, the difficulty of bargaining over wages, or lack of information may prevent this comparison from being a clean test of the theorem, this comparison does seem a better test than some others which have been suggested in the literature.

\section{Conclusions and Main Lessons}

A number of conclusions can be drawn from the four reemployment bonus and six job search experiments. First, the bonus experiments show that economic incentives do affect the speed with which people leave the unemployment insurance rolls. UI is not a completely benign transfer; it affects claimants' behavior. This is shown by the declines in weeks of UI receipt found for all of the bonus treatments, several of which were statistically significant. The experiments also show that speeding claimants' return to work appears to increase total earnings following the claim, but the evidence is less 
strong. Furthermore, the experiments suggest that the rate of pay on the new job is not adversely affected by an earlier return to work. This would be an important finding and would imply that small changes in the generosity of UI are unlikely to affect the reemployment wages of claimants.

Despite these encouraging results, I do not believe that the experiments show that permanent adoption of a reemployment bonus would be beneficial to the UI system or society. The key drawback of the experiments is that they cannot account for the effect of a reemployment bonus on the size of the claimant population. A reemployment bonus makes filing for UI much more valuable, as claimants become eligible for a large payment if they find a job soon. Such a payment is of most value to someone who plans to start a job soon and may not currently think filing for UI is worth the trouble. The UI experiments conclusively show the effect of monetary incentives on the propensity to continue filing for benefits. There would probably be a similar effect on the propensity to file initially as the compensation for short UI spells increases. While this conclusion is pessimistic with regard to reemployment bonuses, it is favorable to the current UI system which pays people for as many weeks as they are unemployed.

The job search experiments test several alternative reforms which appear more promising. The six experiments try various combinations of services to improve job search and increased enforcement of work search rules. Nearly all of these combinations reduce UI receipt, and have benefits that exceed costs. The treatments which mainly increase enforcement of work search rules have small but often statistically significant effects. The experiments which focus more on providing services induce much larger 
reductions in UI receipt, but at a higher cost of services per claimant. Nevertheless, these experiments have very favorable ratios of benefits to costs. An important proviso should be made about the experiments in Nevada and Minnesota which appear to be the most successful in reducing time on UI. The experimental designs have weaknesses and the evaluations of the results are incomplete. A more complete evaluation of these approaches is needed before strong conclusions can be reached. 


\section{$\underline{\text { References }}$}

Anderson, Patricia (1992): "The Effect of a Reemployment Bonus with the Possibility of Recall: Experimental Evidence from New Jersey," Journal of Labor Economics, pp. $99-115$.

Anderson, Patricia M. and Bruce D. Meyer (1992): "Unemployment Insurance Benefits and Takeup Rates." Mimeograph. Evanston, IL: Northwestern University.

Anderson, Patricia, Walter Corson, and Paul Decker (1990): The New Jersey Unemployment Insurance Reemployment Demonstration Project: Follow-Up Report, Unemployment Insurance Occasional Paper 91-1, U.S. Department of Labor, Employment and Training Administration, Unemployment Insurance Service.

Atkinson, A. B. (1987): "Income Maintenance and Social Insurance," in Handbook of Public Economics, ed. by Alan Auerbach and Martin Feldstein. Amsterdam: North-Holland.

Bassi, Laurie J., and Orley Ashenfelter (1986): "The Effect of Direct Job Creation and Training Programs on Low-Skilled Workers," in Fighting Poverty ed. by Sheldon Danziger and Daniel H. Weinberg. Cambridge: Harvard University Press.

Benus, Jacob M., Michelle L. Wood, Christopher J. Napierala, and Terry R. Johnson (1992): "Massachusetts UI Self-Employment Demonstration," in Self-Employment Programs for Unemployed Workers, in Unemployment Insurance Occasional Paper 92-2, U.S. Department of Labor, Employment and Training Administration, Unemployment Insurance Service.

Blank, Rebecca, and David Card (1991): "Recent Trends in Insured and Uninsured Unemployment: Is There an Explanation?" forthcoming, Quarterly Journal of Economics.

Bloom, David E., Richard B. Freeman and Sanders D. Korenman (1987): 'The LabourMarket Consequences of Generational Crowding," European Journal of Population, pp. 131-176.

Brechling, Frank (1981): "Layoffs and Unemployment Insurance." In Studies in Labor Markets, edited by Sherwin Rosen. Chicago: The University of Chicago Press.

Card, David (1990): "The Impact of the Mariel Boatlift on the Miami Labor Market," Industrial and Labor Relations Review, pp. 245-257. 
Clark, Kim B., and Lawrence H. Summers. "Unemployment Insurance and Labor Market Transitions." In Workers, Jobs, and Inflation, edited by Martin Neil Baily. Washington, D.C.: Brookings Institution, 1982.

Corson, Walter S., and Paul T. Decker (1989): "The Impact of Reemployment Services on Unemployment Insurance Benefits: Findings from the New Jersey Unemployment Insurance Reemployment Demonstration," unpublished manuscript, Mathematica Policy Research.

Corson, Walter, Paul T. Decker, Shari Miller Dunstan, and Anne R. Gordon (1989): New Jersey Unemployment Insurance Reemployment Demonstration Project: Final Evaluation Report, Unemployment Insurance Occasional Paper 89-3, U.S. Department of Labor, Employment and Training Administration, Unemployment Insurance Service.

Corson, Walter, Paul Decker, Shari Dunstan, and Stuart Kerachsky (1991): Pennsvlvania Reemployment Bonus Demonstration: Draft Final Report, unpublished manuscript, Mathematica Policy Research.

Corson, Walter, David Long, and Walter Nicholson (1985): Evaluation of the Charleston Claimant Placement and Work Test Demonstration, Unemployment Insurance Occasional Paper 85-2, U.S. Department of Labor, Employment and Training Administration, Unemployment Insurance Service.

Corson, Walter and Walter Nicholson (1988): An Examination of Declining UI Claims During the 1980's, Unemployment Insurance Occasional Paper 88-3, Washington, DC: US Department of Labor - ETA, 1988.

Davidson, Carl, and Stephen A. Woodbury (1991a): "Effects of a Reemployment Bonus under Differing Benefit Entitlements, or, Why the Illinois Experiment Worked," unpublished manuscript, Michigan State University.

Davidson, Carl, and Stephen A. Woodbury (1991b): "The Displacement Effect of Reemployment Bonus Programs," unpublished manuscript, Michigan State University.

Deere, Donald R. "Unemployment Insurance and Employment." Journal of Labor Economics 9 (October 1991): 307-324.

Director, Steven M., and Frederick J. Englander (1980): "Requiring Unemployment Insurance Recipients to Register with the Public Employment Service," Journal of Risk and Insurance, pp. 245-258. 
Donohue, John J. (1989): "Diverting the Coasean River: Incentive Schemes to Reduce Unemployment Spells," Yale Law Journal, 99, 549-609.

Franke, Richard H., and James D. Kaul (1978): "Hawthorne Experiments: First Statistical Interpretations," American Sociological Review, 43, 623-643.

Gibbons, Robert, and Lawrence F. Katz (1991): "Layoffs and Lemons," Journal of Labor Economics, pp. 351-380.

Gottschalk, Peter, and Tim Maloney (1985): "Involuntary Terminations, Unemployment, and Job Matching: A Test of Job Search Theory." Journal of Labor Economics, 3, pp. 109-123.

Gritz, R. Mark, and Thomas MaCurdy (1989): "The Influence of Unemployment Insurance on the Unemployment Experiences of Young Workers." Mimeograph. Stanford, California: Stanford University.

Gueron, Judith M. and Edward Pauly (1991): From Welfare to Work, New York: Russell Sage Foundation.

Hanna, James, and Zina Turney (1990): "The Economic Impact of the Nevada Claimant Employment Program," in UI Research Exchange, Unemployment Insurance Occasional Paper 90-4, U.S. Department of Labor, Employment and Training Administration, Unemployment Insurance Service.

Hausman, Jerry A., and David A. Wise (1985): Social Experimentation. Chicago: University of Chicago Press.

Johnson, George (1979): "The Labor Market Displacement Effect in the Analysis of the Net Impact of Manpower Training Programs," in Evaluating Manpower Training Programs, ed. by Farrell E. Bloch, Research in Labor Economics, Supplement. JAI Press.

Johnson, Terry R., Katherine P. Dickinson, and Richard W. West (1985): "An Evaluation of the Impact of ES Referrals on Applicant Earnings," The Journal of Human Resources, pp. 117- 137.

Johnson, Terry R., and Daniel H. Klepinger (1991): Evaluation of the Impacts of the Washington Alternative Work Search Experiment, Unemployment Insurance Occasional Paper 91-4, U.S. Department of Labor, Employment and Training Administration, Unemployment Insurance Service. 
Johnson, Terry R., and Janice J. Leonard (1992): "Washington State Self-Employment and Enterprise Development (SEED) Demonstration," in Self-Employment Programs for Unemploved Workers, in Unemployment Insurance Occasional Paper 92-2, U.S. Department of Labor, Employment and Training Administration, Unemployment Insurance Service.

Katz, Arnold (1980): "Nonexperimental Evaluations of Employment Service Influence on Search Times and Earnings," in Annual Review of Research in Vocational Education. Vol 1., ed. by Tim L. Wentling. Champagne: University of Illinois Press.

Katz, Lawrence F. (1985): "Worker Mobility and Unemployment," Ph.D. Dissertation, MIT.

Katz, Lawrence F., and Bruce D. Meyer (1991): "Unemployment Insurance, Recall Expectations and Unemployment Outcomes," Quarterly Journal of Economics, CV, November 1990, 973-1002.

Kerachsky, Stuart, and Walter Corson (1989): "Alternative Uses of Unemployment Insurance: The Unemployment Insurance Demonstrations," in The Secretary's Seminars on Unemployment Insurance, Unemployment Insurance Occasional Paper 89-1, U.S. Department of Labor, Employment and Training Administration, Unemployment Insurance Service.

LaLonde, Robert J. (1992): "The Earnings Impact of U.S. Employment and Training Programs," prepared for the Employment and Immigration Canada Conference on Policy Research in Training, Unemployment, Income Support, and Immigration.

Levine, Phillip B. (1991a); "Testing Search Theory with Reemployment Bonus Experiments: Cross-Validation of Results from New Jersey and Illinois," working paper, Wellesley College.

Levine, Phillip B. (1991b): "Spillover Effects Between the Insured and Uninsured Unemployed," working paper, Wellesley College.

Meyer, Bruce D. (1989): "A Quasi-Experimental Approach to the Effects of Unemployment Insurance," NBER Working Paper No. 3159.

Meyer, Bruce D. (1991): "What Have We Learned from the Illinois Bonus Experiment?" working paper, Northwestern University.

Meyer, Bruce D. (1992): "Quasi-Experimental Evidence on the Effects of Unemployment Insurance from New York State," working paper, Northwestern University. 
Mincer, Jacob (1991): "Education and Unemployment." NBER Working Paper No. 3838, September 1991.

Minnesota Department of Jobs and Training (1990): "Re-Employ Minnesota, S.Sn

Reemployment Services to Unemployed Workers Having Difficulty Becoming

Reemployed, Unemployment Insurance Occasional Paper 90-2, U.S. Department of Labor, Employment and Training Administration, Unemployment Insurance Service, pp. 68-73.

Minnesota Department of Jobs and Training (1990): "Re-Employ Minnesota: Overview," mimeo.

Minnesota Department of Jobs and Training (1991): "Methodology for REM-Expansion Project" mimeo.

Moffitt, Robert (1983): "An Economic Model of Welfare Stigma," American Economic Review, 73, 1023-1035.

Moffitt, Robert (1992): "Evaluation Methods for Program Entry Effects," in Evaluating Welfare and Training Programs, edited by Charles F. Manski and Irwin Garfinkel. Cambridge, MA: Harvard University Press.

Moffitt, Robert, and Walter Nicholson (1982): "The Effect of Unemployment Insurance on Unemployment: The Case of Federal Supplemental Benefits," The Review of Economics and Statistics, 64, 1-11.

Mortensen, Dale T. (1987): "The Effects of a UI Bonus on Job Search," mimeo, Northwestern University.

Mortensen, Dale T. (1988): "A Structural Model of UI Benefit Effects on the Incidence and Duration of Unemployment," mimeo, Northwestern University.

Nathan, Richard P. (1988): Social Science in Government. New York: Basic Books.

Romero, Carol J., Donald Cox and Arnold Katz (1991): "The Potential Effectiveness of the Employment Service in Serving Dislocated Workers under EDWAA: Evidence from the 1980s," National Commission for Employment Policy.

Osberg, Lars (1988): "An Evaluation of the Efficiency and Equity Implications of CEC use in Job Search Activity," paper prepared for the Program Evaluation Branch, Employment and Immigration Canada. 
Shavell, Steven and Laurence Weiss (1979): "The Optimal Payment of Unemployment Insurance Benefits over Time," Journal of Political Economy, 87, 1347-1362.

Solow, Robert M. (1980): "Employment Policy in Inflationary Times," in Employing the Unemployed, ed. by Eli Ginzberg. New York: Basic Books.

Spiegelman, Robert G., Christopher J. O'Leary, and Kenneth J. Kline (1991): The Washington Reemployment Bonus Experiment: Final Report. Kalamazoo: W. E. Upjohn Institute for Employment Research.

Spiegelman, Robert G., and Stephen A. Woodbury (1987): The Illinois Unemployment Insurance Incentive Experiments: Final Report. Kalamazoo: W. E. Upjohn Institute for Employment Research.

Steinman, John P. (1978): "The Nevada Claimant Placement Program," Employment Security Research, Nevada Employment Security Department.

Topel, Robert H. (1983): "On Layoffs and Unemployment Insurance." American Economic Review, 73, 541-559.

Vroman, Wayne (1991): The Decline in Unemployment Insurance Claims Activity in the 1980's, Unemployment Insurance Occasional Paper 91-2, Washington, DC: US Department of Labor - ETA.

Woodbury, Stephen A., and Robert G. Spiegelman (1987): "Bonuses to Workers and Employers to Reduce Unemployment: Randomized Trials in Illinois," American Economic Review, 77, 513-530. 
Table 1

Main Design Characteristics of the Four Bonus Experiments

\begin{tabular}{|c|c|c|}
\hline & $\begin{array}{l}\text { Illinois UI Incentive } \\
\text { Experiments }\end{array}$ & $\begin{array}{l}\text { New Jersey UI Reemployment } \\
\text { Demonstration }\end{array}$ \\
\hline $\begin{array}{l}\text { Enrollment } \\
\text { period }\end{array}$ & July 1984 to November 1984 & July 1986 to June 1987 \\
\hline Bonus amount & $\$ 500$ for all claimants & $\begin{array}{l}1 / 2 \text { of remaining entitlement, but } \\
\text { declining } 10 \% \text { per week }\end{array}$ \\
\hline $\begin{array}{l}\text { Relative bonus } \\
\text { amount }\end{array}$ & $\begin{array}{l}\text { About } 4 \text { times average weekly } \\
\text { benefit }\end{array}$ & $\begin{array}{l}\text { About } 10 \text { times weekly benefit at } \\
\text { beginning, } \$ 1,644 \text { on average }\end{array}$ \\
\hline $\begin{array}{l}\text { When bonus } \\
\text { offer made }\end{array}$ & At Job Service registration & $\begin{array}{l}\text { Approximately } 5 \text { weeks after } \\
\text { claim filed }\end{array}$ \\
\hline $\begin{array}{l}\text { Qualification } \\
\text { period }\end{array}$ & 11 weeks for all claimants & $\begin{array}{l}10 \text { weeks, but beginning about } 7 \\
\text { weeks after claim }\end{array}$ \\
\hline $\begin{array}{l}\text { Reemployment } \\
\text { period }\end{array}$ & 4 months & $\begin{array}{l}60 \% \text { of bonus after } 4 \text { weeks, } \\
\text { rest after } 12\end{array}$ \\
\hline $\begin{array}{l}\text { Population } \\
\text { examined }\end{array}$ & $\begin{array}{l}20-55 \text { year olds without definite } \\
\text { recall date, or membership in } \\
\text { union using hiring halls }\end{array}$ & $\begin{array}{l}\text { Excluded those under } 25 \text {, those } \\
\text { with definite recall date, } \\
\text { members of unions using hiring } \\
\text { halls and those with tenure less } \\
\text { than } 3 \text { years. }\end{array}$ \\
\hline $\begin{array}{l}\text { Eligibility for } \\
\text { bonus }\end{array}$ & No exclusions & $\begin{array}{l}\text { Those returning to pre-UI } \\
\text { employer ineligible }\end{array}$ \\
\hline Sample sizes & $\begin{array}{l}3,952 \text { in control group, } \\
8,149 \text { in } 2 \text { treatment groups }\end{array}$ & $\begin{array}{l}2,385 \text { in control group, } \\
8,675 \text { in } 6 \text { treatment groups }\end{array}$ \\
\hline
\end{tabular}

(continued)

\section{Other Important Characteristics}

Illinois: a second treatment paid the $\$ 500$ bonus to the employer.

New Jersey: 3 treatments were tried, mandatory job-search assistance (JSA) only, JSA plus relocation assistance and training, and JSA plus bonus. The bonus only became available about 7 weeks after filing for UI benefits. 
Table 1 -Continued

\begin{tabular}{|c|c|c|}
\hline & $\begin{array}{l}\text { Pennsylvania } \\
\text { Reemployment Bonus } \\
\text { Demonstration }\end{array}$ & $\begin{array}{l}\text { Washington } \\
\text { Reemployment Bonus } \\
\text { Experiments }\end{array}$ \\
\hline $\begin{array}{l}\text { Enrollment } \\
\text { period }\end{array}$ & July 1988 to October 1989 & $\begin{array}{l}\text { February } 1988 \text { to November } \\
1988\end{array}$ \\
\hline Bonus Amount & $\begin{array}{l}2 \text { levels: } 3 \text { and } 6 \text { times the } \\
\text { weekly benefit amount }\end{array}$ & $\begin{array}{l}3 \text { levels: } 2,4 \text { and } 6 \text { times the } \\
\text { weekly benefit amount }\end{array}$ \\
\hline $\begin{array}{l}\text { Relative bonus } \\
\text { amount }\end{array}$ & $\begin{array}{l}3 \text { times the weekly benefit } \\
\text { averaged about } \$ 500\end{array}$ & $\begin{array}{l}\text { Offer varied from } \$ 110-\$ 1,254 \text {; } \\
\text { average offer of } \$ 562\end{array}$ \\
\hline $\begin{array}{l}\text { When bonus } \\
\text { offer made }\end{array}$ & $\begin{array}{l}\text { After first payment or waiting } \\
\text { week }\end{array}$ & When claim filed \\
\hline $\begin{array}{l}\text { Qualification } \\
\text { period }\end{array}$ & 2 levels: 6 and 12 weeks & $\begin{array}{l}2 \text { levels: } .2 \text { times potential } \\
\text { duration }+1 \text { week, and } .4 \text { times } \\
\text { potential duration }+1 \text { week ( } 3 \text { - } \\
13 \text { weeks) }\end{array}$ \\
\hline $\begin{array}{l}\text { Reemployment } \\
\text { period }\end{array}$ & 16 weeks & 4 inonths \\
\hline $\begin{array}{l}\text { Population } \\
\text { examined }\end{array}$ & $\begin{array}{l}\text { Excluded those with definite } \\
\text { recall date of less than } 60 \text { days, } \\
\text { and those who obtained jobs } \\
\text { exclusively through their union }\end{array}$ & No important restrictions \\
\hline $\begin{array}{l}\text { Eligibility for } \\
\text { bonus }\end{array}$ & $\begin{array}{l}\text { Those recalled by pre-layoff } \\
\text { employer ineligible }\end{array}$ & $\begin{array}{l}\text { Those who returned to same job } \\
\text { or hired through union hiring } \\
\text { hall ineligible }\end{array}$ \\
\hline Sample sizes & $\begin{array}{l}3,392 \text { in control group, } 10,694 \\
\text { in } 6 \text { treatment groups }\end{array}$ & $\begin{array}{l}3,082 \text { in control group, } 12,452 \\
\text { in } 6 \text { treatment groups }\end{array}$ \\
\hline
\end{tabular}

\section{Other Important Characteristics}

Pennsylvania: five of six treatments were combined with an optional job search workshop. A fifth treatment group had a bonus amount which declined from 6 times the weekly UI benefit over a 12-week period. A sixth treatment was a bonus amount of 6 times the weekly UI benefit with a 12-week qualification period, but no job search workshop. 
Table 2

Effects of the Bonus Experiments on Weeks of Benefits and Reemployment Earnings Measured as Treatment Minus Control

(standard errors in parentheses)

\begin{tabular}{|c|c|c|c|}
\hline \multirow[b]{2}{*}{ State and Treatment } & \multicolumn{2}{|c|}{$\begin{array}{l}\text { Weeks of Benefits } \\
\text { in Benefit Year }\end{array}$} & \multirow[b]{2}{*}{$\begin{array}{c}\text { Quarterly Reemployment } \\
\text { Earnings (\$) }\end{array}$} \\
\hline & $\begin{array}{l}\text { Without } \\
\text { Regressors }\end{array}$ & $\begin{array}{l}\text { With } \\
\text { Regressors }\end{array}$ & \\
\hline \multicolumn{4}{|c|}{ Illinois UI Incentive Experiments } \\
\hline 1. Claimant Experiment & $\begin{array}{l}-1.15 \\
(0.29)\end{array}$ & & $\begin{array}{c}8 \\
(66)\end{array}$ \\
\hline 2. Employer Experiment & $\begin{array}{l}-0.36 \\
(0.27)\end{array}$ & & $\begin{array}{l}-55 \\
(66)\end{array}$ \\
\hline \multicolumn{4}{|l|}{$\begin{array}{l}\text { New Jersey UI Reemployment } \\
\text { Demonstration }\end{array}$} \\
\hline 1a. JSA Plus Bonus & $\begin{array}{l}-0.90 \\
(0.25)\end{array}$ & $\begin{array}{l}-0.97 \\
(0.24)\end{array}$ & $\begin{array}{c}79 \\
(85)\end{array}$ \\
\hline 1b. JSA only & $\begin{array}{l}-0.50 \\
(0.25)\end{array}$ & $\begin{array}{l}-0.47 \\
(0.24)\end{array}$ & $\begin{array}{c}31 \\
(86)\end{array}$ \\
\hline $\begin{array}{l}\text { 1c. ISA Plus Bonus } \\
\text { Minus ISA only }\end{array}$ & $\begin{array}{l}-0.40 \\
(0.25)\end{array}$ & & \\
\hline \multicolumn{4}{|l|}{$\begin{array}{l}\text { Pennsylvania Reemployment } \\
\text { Bonus Demonstration }\end{array}$} \\
\hline $\begin{array}{l}\text { 1. Low Bonus, Short } \\
\text { Qualification Period }\end{array}$ & $\begin{array}{l}-0.41 \\
(0.34)\end{array}$ & $\begin{array}{l}-0.65 \\
(0.34)\end{array}$ & $\begin{array}{c}-171 \\
(87)\end{array}$ \\
\hline $\begin{array}{l}\text { 2. Low Bonus, Long } \\
\text { Qualification Period }\end{array}$ & $\begin{array}{l}-0.44 \\
(0.28)\end{array}$ & $\begin{array}{l}-0.36 \\
(0.28)\end{array}$ & $\begin{array}{c}54 \\
(75)\end{array}$ \\
\hline $\begin{array}{l}\text { 3. High Bonus, Short } \\
\text { Qualification Period }\end{array}$ & $\begin{array}{l}-0.49 \\
(0.31)\end{array}$ & $\begin{array}{l}-0.44 \\
(0.29)\end{array}$ & $\begin{array}{c}97 \\
(85)\end{array}$ \\
\hline $\begin{array}{l}\text { 4. High Bonus, Long } \\
\text { Qualification Period }\end{array}$ & $\begin{array}{l}-0.92 \\
(0.27)\end{array}$ & $\begin{array}{l}-0.82 \\
(0.26)\end{array}$ & $\begin{array}{l}120 \\
(70)\end{array}$ \\
\hline $\begin{array}{l}\text { 5. Initially High but } \\
\text { Declining Bonus, Long } \\
\text { Qualification Period }\end{array}$ & $\begin{array}{l}-0.19 \\
(0.31)\end{array}$ & $\begin{array}{l}-0.33 \\
(0.30)\end{array}$ & $\begin{array}{c}77 \\
(82)\end{array}$ \\
\hline
\end{tabular}


Table 2-Continued

(standard errors in parentheses)

\begin{tabular}{|c|c|c|c|}
\hline \multirow[b]{2}{*}{ State and Treatment } & \multicolumn{2}{|c|}{$\begin{array}{l}\text { Weeks of Benefits } \\
\text { in Benefit Year }\end{array}$} & \multirow[b]{2}{*}{$\begin{array}{c}\text { Quarterly Reeniployment } \\
\text { Earnings ( } \$ \text { ) }\end{array}$} \\
\hline & $\begin{array}{l}\text { Without } \\
\text { Regressors }\end{array}$ & $\begin{array}{l}\text { With } \\
\text { Regressors }\end{array}$ & \\
\hline \multicolumn{4}{|l|}{$\begin{array}{l}\text { Washington Reemployment } \\
\text { Bonus Experiments }\end{array}$} \\
\hline $\begin{array}{l}\text { 1. Low Bonus, Short } \\
\text { Qualification Period }\end{array}$ & $\begin{array}{l}-0.06 \\
(0.30)\end{array}$ & $\begin{array}{l}-0.04 \\
(0.29)\end{array}$ & $\begin{array}{l}-56 \\
(114)\end{array}$ \\
\hline $\begin{array}{l}\text { 2. Medium Bonus, Short } \\
\text { Qualification Period }\end{array}$ & $\begin{array}{l}-0.18 \\
(0.30)\end{array}$ & $\begin{array}{l}-0.27 \\
(0.29)\end{array}$ & $\begin{array}{c}-89 \\
(113)\end{array}$ \\
\hline $\begin{array}{l}\text { 3. High Bonus, Short } \\
\text { Qualification Period }\end{array}$ & $\begin{array}{l}-0.62 \\
(0.34)\end{array}$ & $\begin{array}{l}-0.70 \\
(0.33)\end{array}$ & $\begin{array}{c}-93 \\
(127)\end{array}$ \\
\hline $\begin{array}{l}\text { 4. Low Bonus, Long } \\
\text { Qualification Period }\end{array}$ & $\begin{array}{l}-0.51 \\
(0.30)\end{array}$ & $\begin{array}{l}-0.62 \\
(0.29)\end{array}$ & $\begin{array}{c}-77 \\
(112)\end{array}$ \\
\hline $\begin{array}{l}\text { 5. Medium Bonus, Long } \\
\text { Qualification Period }\end{array}$ & $\begin{array}{l}-0.14 \\
(0.30)\end{array}$ & $\begin{array}{l}-0.26 \\
(0.29)\end{array}$ & $\begin{array}{c}-78 \\
(112)\end{array}$ \\
\hline $\begin{array}{l}\text { 6. High Bonus, Long } \\
\text { Qualification Period }\end{array}$ & $\begin{array}{l}-0.73 \\
(0.34)\end{array}$ & $\begin{array}{l}-0.75 \\
(0.33)\end{array}$ & $\begin{array}{c}-22 \\
(127)\end{array}$ \\
\hline
\end{tabular}

Sources: Published reports, unpublished Pennsylvania tabulations, and the author's calculations.

Notes: (1) To aid interpretation of the results, the control group mean weeks of benefits were 20.1, $17.9,14.9,15.2$ in Illinois, New Jersey, Pennsylvania and Washington, respectively. Quarterly earnings were $\$ 3,121,2,517$ and 2,605 in the first 3 states; control group earnings are unavailable for Washington. (2) The earnings measure for Illinois is earnings in the quarter after benefit termination, for New Jersey is earnings in the 4 th quarter after claim, for Pennsylvania is earnings in the 3rd quarter after claim, and for Washington is eamings in the 1st quarter after the end of UI receipt. The New Jersey and Washington earnings numbers are the coefficients on dummy variables for the different treatments from regressions with demographic variables. The Illinois and Washington earnings numbers are for those with positive earnings. (3) The sixth Pennsylvania treatment group that did not receive the voluntary job search workshop has been combined with the fourth treatment group in this table. See the text for a discussion. 
Table 3

Main Design Characteristics of the Job Search Experiments.

\begin{tabular}{|c|c|c|}
\hline & $\begin{array}{l}\text { Nevada Claimant } \\
\text { Placement Program (NCPP) }\end{array}$ & $\begin{array}{l}\text { Charleston Claimant } \\
\text { Placement and Work } \\
\text { Test Demonstration }\end{array}$ \\
\hline $\begin{array}{l}\text { Enrollment } \\
\text { period }\end{array}$ & February 1977 to March 1978 & February 1983 to December 1983 \\
\hline Treatments & $\begin{array}{l}\text { One treatment: more intensive } \\
\text { services, weekiy interviews and } \\
\text { eligibility checks, all services } \\
\text { from same ES/UI team }\end{array}$ & $\begin{array}{l}\text { Three treatments: (1) } 2 \text { enhanced } \\
\text { placement interviews and a } 3 \text {-hour } \\
\text { job search assistance session } \\
\text { required; (2) } 2 \text { interviews only; (3) } \\
1 \text { interview only }\end{array}$ \\
\hline $\begin{array}{l}\text { When first } \\
\text { contacted }\end{array}$ & After 3rd UI payment & After Ist UI payment \\
\hline $\begin{array}{l}\text { Population } \\
\text { examined }\end{array}$ & All eligible claimants & Mass layoff claimants excluded \\
\hline Sample sizes & $\begin{array}{l}1,174 \text { in control group, } 2,371 \text { in } \\
\text { treatment group }\end{array}$ & $\begin{array}{l}1,428 \text { in control group, } \\
4,247 \text { in } 3 \text { treatment groups }\end{array}$ \\
\hline
\end{tabular}


Table 3-Continued

\begin{tabular}{|c|c|c|}
\hline & $\begin{array}{l}\text { New Jersey UI } \\
\text { Reemployment } \\
\text { Demonstration }\end{array}$ & $\begin{array}{l}\text { Nevada Claimant } \\
\text { Employment Program (NCEP) }\end{array}$ \\
\hline $\begin{array}{l}\text { Enrollment } \\
\text { period }\end{array}$ & July 1986 to June 1987 & July 1988 to June 1989 \\
\hline Treatments & $\begin{array}{l}\text { Two treatments: } \\
\text { (1) periodic contacts with } \\
\text { Employment Service required, } \\
\text { job search materials provided } \\
\text { (JSA); (2) JSA plus offer of } \\
\text { training and relocation } \\
\text { assistance }\end{array}$ & $\begin{array}{l}\text { One treatment: higher quality ES } \\
\text { and UI services, all services from } \\
\text { same ES/UI team }\end{array}$ \\
\hline $\begin{array}{l}\text { When first } \\
\text { contacted }\end{array}$ & $\begin{array}{l}\text { Approximately } 5 \text { weeks after } \\
\text { claim filed }\end{array}$ & 4 weeks into benefit year \\
\hline $\begin{array}{l}\text { Population } \\
\text { examined }\end{array}$ & $\begin{array}{l}\text { Excluded those under } 25 \text {, those } \\
\text { with a definite recall date, } \\
\text { members of unions using hiring } \\
\text { halls, and those with tenure less } \\
\text { than } 3 \text { years }\end{array}$ & All eligible claimants \\
\hline Sample sizes & $\begin{array}{l}2,385 \text { in control group, } 6,226 \text { in } \\
2 \text { treatment groups }\end{array}$ & $\begin{array}{l}1,538 \text { in control group } \\
1,424 \text { in treatment group }\end{array}$ \\
\hline
\end{tabular}

(continued)

\section{Other Important Characteristics}

New Jersey UI Reemployment Demonstration: the job search assistance treatments were part of the larger New Jersey UI Reemployment Demonstration which is also described in the bonus experiment section.

Nevada Claimant Employment Program: this experiment also had a training program which is described briefly in the text. 
Table 3-Continued

\begin{tabular}{|c|c|c|}
\hline & $\begin{array}{l}\text { Washington Alternative } \\
\text { Work Search Experiment }\end{array}$ & Reemploy Minnesota Project \\
\hline $\begin{array}{l}\text { Enrollment } \\
\text { period }\end{array}$ & July 1986 to August 1987 & July 1988 to June 1990 \\
\hline Treatments & $\begin{array}{l}\text { Three treatments: (1) exception } \\
\text { reporting based on the honor } \\
\text { system; (2) individually tailored } \\
\text { work search; (3) intensive work } \\
\text { search assistance with } 2 \text {-day job } \\
\text { search workshop }\end{array}$ & $\begin{array}{l}\text { One treatment: intensive } \\
\text { personalized job search assistance, } \\
\text { all services from same staff person }\end{array}$ \\
\hline $\begin{array}{l}\text { When first } \\
\text { contacted }\end{array}$ & $\begin{array}{l}\text { At interview following claim } \\
\text { filing }\end{array}$ & At claim filing \\
\hline $\begin{array}{l}\text { Population } \\
\text { examined }\end{array}$ & All eligible claimants & $\begin{array}{l}\text { All claimants not attached to an } \\
\text { employer and without separation } \\
\text { issues }\end{array}$ \\
\hline Sample sizes & $\begin{array}{l}2,871 \text { in control group, } 6,763 \text { in } \\
3 \text { treatment groups }\end{array}$ & $\begin{array}{l}\text { Unknown number in control group, } \\
4,212 \text { in treatment group }\end{array}$ \\
\hline
\end{tabular}


Table 4

Effects of the Job Search Experiments on Weeks of Benefits and Reemployment Earnings Measured as Treatment Minus Control

(standard errors in parentheses)

\begin{tabular}{|c|c|c|c|}
\hline \multirow[b]{2}{*}{ State and Treatment } & \multicolumn{2}{|c|}{ Weeks of Benefits } & \multirow[b]{2}{*}{$\begin{array}{l}\text { Reemployment } \\
\text { Eamings (\$) }\end{array}$} \\
\hline & $\begin{array}{l}\text { Without } \\
\text { Regressors }\end{array}$ & $\begin{array}{l}\text { With } \\
\text { Regressors }\end{array}$ & \\
\hline $\begin{array}{l}\text { Nevada Claimant Placement } \\
\text { Program (NCPP) }\end{array}$ & $\begin{array}{l}-3.90 \\
(0.41)^{\circ}\end{array}$ & & \\
\hline \multicolumn{4}{|l|}{$\begin{array}{l}\text { Charleston Claimant } \\
\text { Placement and Work } \\
\text { Test Demonstration }\end{array}$} \\
\hline $\begin{array}{l}\text { 1. } 2 \text { Interviews and } \\
\text { Job Search Session }\end{array}$ & $\begin{array}{l}-0.70 \\
(0.39)\end{array}$ & $\begin{array}{l}-0.76 \\
(0.38)\end{array}$ & \\
\hline 2. 2 Interviews Only & $\begin{array}{l}-0.50 \\
(0.37)\end{array}$ & $\begin{array}{l}-0.61 \\
(0.36)\end{array}$ & \\
\hline 3. 1 Interview Only & $\begin{array}{l}-0.50 \\
(0.38)\end{array}$ & $\begin{array}{l}-0.55 \\
(0.37)\end{array}$ & \\
\hline \multicolumn{4}{|l|}{$\begin{array}{l}\text { New Jersey UI Reemployment } \\
\text { Demonstration }\end{array}$} \\
\hline $\begin{array}{l}\text { 1. Job-Search Assistance } \\
\text { (JSA) }\end{array}$ & $\begin{array}{l}-0.50 \\
(0.25)\end{array}$ & $\begin{array}{l}-0.47 \\
(0.24)\end{array}$ & $\begin{array}{c}31 \\
(86)\end{array}$ \\
\hline $\begin{array}{l}\text { 2. JSA Plus Training and } \\
\text { Relocation Assistance }\end{array}$ & $\begin{array}{l}-0.50 \\
(0.22)\end{array}$ & $\begin{array}{l}-0.48 \\
(0.22)\end{array}$ & $\begin{array}{c}28 \\
(77)\end{array}$ \\
\hline \multicolumn{4}{|c|}{$\begin{array}{l}\text { Nevada Claimant } \\
\text { Employment Program (NCEP) }\end{array}$} \\
\hline Including Trainees & $\begin{array}{l}-1.60 \\
(0.30)\end{array}$ & & \\
\hline Excluding Trainees & $\begin{array}{l}-2.10 \\
(0.29)\end{array}$ & & \\
\hline
\end{tabular}


Table 4-Continued

(standard errors in parentheses)

Weeks of Benefits

$\begin{array}{llll}\text { State and Treatment } & \text { Without } & \text { With } & \text { Reemployment } \\ & \text { Regressors } & \text { Regressors } & \text { Earnings (\$) }\end{array}$

\begin{tabular}{|c|c|c|c|}
\hline \multicolumn{4}{|l|}{$\begin{array}{l}\text { Washington Alternative } \\
\text { Work Search Experiment }\end{array}$} \\
\hline 1. Exception Reporting & & $\begin{array}{c}3.34 \\
(0.29)\end{array}$ & $\begin{array}{c}-23 \\
(220)\end{array}$ \\
\hline $\begin{array}{l}\text { 2. Individually Tailored } \\
\text { Work Search }\end{array}$ & & $\begin{array}{c}0.17 \\
(0.30)\end{array}$ & $\begin{array}{l}-24 \\
(224)\end{array}$ \\
\hline 3. Intensive Work Search & & $\begin{array}{l}-0.47 \\
(0.28)\end{array}$ & $\begin{array}{c}292 \\
(211)\end{array}$ \\
\hline Re-Employ Minnesota Project & $\begin{array}{l}-4.32 \\
(0.16)^{\circ}\end{array}$ & & \\
\hline
\end{tabular}

Sources: Published reports and the author's calculations.

The standard error has been estimated using the reported sample sizes and a standard deviation of weeks of benefits of 10 .

Notes: To aid interpretation of the results, the control group mean weeks of benefits was $12.4,15.5$, $17.9,14.0,14.5$ and 16.0 for the six experiments in the order listed above. The control group earnings in New Jersey were $\$ 2,517$ and in Washington $\$ 9,919$. In the NCPP the UI weeks measure is for the first spell, and for the sample excluding union members. In New Jersey the UI weeks measure is for the Benefit Year, earnings are for the 4 th quarter after claim with regression controls. In Charleston the UI benefits measure is for the first 6 months of the claim. In the NCEP the exact measure of weeks of UI is not defined in the report. In Washington the UI weeks measure is for the Benefit Year, and eamings are for the year following the claim. In Minnesota the exact measure of weeks of UI is not defined in the reports. 